\title{
Peach cultivars from tropical regions: characterization and processing potential
}

\author{
Paula Nogueira Curi ${ }^{1}$ Bruna de Sousa Tavares ${ }^{2}$ Maraísa Hellen Tadeu ${ }^{1}$ \\ Evaldo Tadeu de Melo ${ }^{1}$ Rafael Pio ${ }^{1}$ Vanessa Rios de Souza ${ }^{1 *, 2}$
}

${ }^{1}$ Departamento de Ciência dos Alimentos, Universidade Federal de Lavras (UFLA), 37200.000, Lavras, MG, Brasil. E-mail: vanessardsouza@gmail.com. "Corresponding author.

${ }^{2}$ Departamento de Agricultura, Universidade Federal de Lavras (UFLA), Lavras, MG, Brasil.

\begin{abstract}
In order to increase the availability to consumers and add even more value to peaches (Prunus persica (L.) Batsch) and to identify which cultivars grown in tropical regions are more suitable for jelly processing, the objective of this study was to characterize and evaluate the influence of different peach cultivars ('Aurora', 'Biuti', 'Bonão', 'Centenário', 'Diamante', 'Douradão', 'Libra', 'Régis' and 'Tropical') cultivated in tropical regions on the physicochemical characteristics, rheological properties and sensory acceptance of the resulting jelly. The evaluated cultivars presented great variability among themselves in relation to the physical and physicochemical characteristics. The jellies elaborated from these cultivars; although, presenting great variability in relation to the physicochemical and rheological parameters, presented similar, high acceptance. All cultivars studied are suitable for processing and can be used for industrialization.

Key words: Prunus persica (L.) Batsch, sensory quality, processing.
\end{abstract}

Cultivares de pêssego de regiões tropicais: caracterização e potencial de processamento

RESUMO: Com o objetivo de aumentar a disponibilidade para os consumidores, agregar ainda mais valor aos pêssegos (Prunus persica (L.) Batsch) e identificar quais cultivares cultivadas em regiões tropicais são mais adequadas para o processamento de geleia, o objetivo deste estudo foi caracterizar e avaliar a influência de diferentes cultivares de pessegueiro ('Aurora', 'Biuti', 'Bonão', 'Centenário', 'Diamante', 'Douradão', 'Libra', 'Régis'e 'Tropical') cultivadas em regiões tropicais nas características físico-químicas, reológicas e sensoriais da geleia resultante. Verificou-se que as cultivares avaliadas apresentaram grande variabilidade entre si em relação às características físicas e fisico-químicas. As geleias elaboradas a partir destas cultivares, embora apresentam grande variabilidade em relação aos parâmetros físicoquímicos e reológicos, apresentaram alta aceitação. Conclui-se, que todas as cultivares estudadas são indicadas para processamento e podem ser destinadas à industrialização.

Palavras-chave: Prunus persica (L.) Batsch, qualidade sensorial, processamento.

\section{INTRODUCTION}

The peach tree produces fruits with very pleasant aroma and color that are part of the economic importance fruits list, not only for their exotic appearance, but also for being a source rich in carotenoids and minerals (CANTÍN et al., 2009). Due to its excellent organoleptic quality, the peach is very appreciated in Brazil, as evidenced by the continuous increase in the consumption of the fruit in fresh or processed in the form of several products, usually available in the market, which has provided increasing interest in its commercial cultivation. In 2015, Brazil imported about 3,980 tons of peach for fresh consumption and 7,031 tons of processed peaches (IBGE, 2016). This shows a great market potential in Brazil and since domestic production has not yet reached enough volume to meet domestic demand, efforts have been made, especially towards the production of peaches in subtropical and tropical regions (SOUZA et al., 2013).

The peach tree (Prunus persica) is a temperate climate species, but some cultivars have been developed for growth in subtropical and tropical regions. Adoption of peach cultivars that require fewer cold units in mild winter regions makes it possible to harvest the fruits in times of lower supply (BARBOSA et al., 2010). This is due to the early harvest of early peaches in southeastern Brazil occurring in anticipated times in relation to the traditional producing regions of Rio Grande do Sul and Santa Catarina (ARAÚJO 
et al., 2008). In addition to the exploitation of the peach tree in subtropical and tropical regions, fruits are harvested at a time when there is a peach shortage in the Brazilian market, obtaining better prices when marketed as fresh fruit, it still allows the production of high-quality processed products. This is because during the peach harvest season in Minas Gerais there are few precipitation providing better quality fruits, both intrinsic and extrinsic (SOUZA et al., 2013).

Due to the availability of several peach cultivars, it is necessary to survey the cultivars that are most suitable and indicated for processing. One way to raise consumption and add even more value to the final product is through processing or industrialization through the manufacture of juices and jellies (KAPOOR \& RANOTE, 2016). In this context, the objective of this study was to characterize and evaluate the influence of different peach cultivars ('Aurora', 'Biuti', 'Bonão', 'Centenário', 'Diamante', 'Douradão', 'Libra', 'Régis' and 'Tropical') cultivated in tropical regions on the physicochemical characteristics, rheological properties and sensory acceptance of the resulting jelly in order to identify the cultivars with the greatest potential for industrial use and to verify which cultivars present a wide range of consumption in the region of Minas Gerais.

\section{MATERIALS AND METHODS}

The peaches were manually harvested in the orchard of the fruit sector of the Universidade Federal de Lavras, Lavras - MG (Brazil) when they presented their physiological maturity (based on size and color). As soon as these fruits were collected, they were transported at room temperature in plastic boxes to the Post-Harvest Laboratory of the Universidade Federal de Lavras, Lavras - MG (Brazil), where they immediately were selected for size, uniformity and maturation and were then cold stored $\left(10^{\circ} \mathrm{C}\right)$. The cultivars used in this work were: 'Aurora', 'Biuti', 'Bonão', 'Centenário', 'Diamante', 'Douradão', 'Libra', 'Régis' and 'Tropical'.

The city is located at $21^{\circ} 14^{\prime}$ 'South latitude and $45^{\circ} 00^{\prime}$ 'West longitude, at an average altitude of 918 meters. The climate is tropical climate of altitude, with dry winter and rainy summer (ALVARES et al., 2013).

Nine jelly formulations were elaborated, and the only variation during the elaboration process was the peach cultivar. After the sanitization in chlorinated water the fruits were homogenized with $50 \%$ water for about 5 minutes in an industrial Poly model mixer. LS-4 (Siemsen, SC, Brazil) with 4.0L capacity at a speed of $3500 \mathrm{rpm}$. Subsequently, to obtain the clarified juice the pulp obtained was passed through a fine mesh sieve. For the preparation of the jellies $65 \%$ of the clarified peach juice, $35 \%$ sugar, $1 \%$ high methoxylation pectin (Danisco, São Paulo, Brazil) and $0.5 \%$ citric acid were used. Initially, the sugar and pulp were combined and heated in an open pan with gas flame (Macanuda, SC, Brazil). When the soluble solids reached $65^{\circ}$ Brix, heating was stopped. After finishing the jellies, they were placed in $250 \mathrm{ml}$ sterile glass jars, cooled to room temperature and stored at a temperature of $7^{\circ} \mathrm{C}$ until the moment of analysis.

To characterize the different cultivars were carried out analyzes of length, diameter, pulp/pit ratio, soluble solids (SS), total acidity (TA), soluble solids/total acidity (ratio), $\mathrm{pH}$ and color on fresh fruits in three replicates. Total soluble solids, $\mathrm{pH}$, total titratable acidity, color ( $\mathrm{L}^{*}$, Chroma and $\left.{ }^{\circ} \mathrm{Hue}\right)$, texture profile analysis and sensorial analysis were analyzed in the jellies.

Length and diameter of the fruits were measured using a 150mm digital pachymeter (Kingtools, $\mathrm{SP}$, Brazil) and a pulp/pit ratio (P/P) was performed using a semi analytical balance AUX220 (Shimadzu, SP, Brazil). Total acidity, soluble solids and $\mathrm{pH}$ values were determined according to the Adolfo Lutz Institute (IAL, 2005). For the Brix degree, the total soluble solids were measured by a RT- 82 portable refractometer. The color with $\mathrm{L}^{*}$, Chroma and ${ }^{\circ} \mathrm{Hue}$ values were determined using a Minolta CR 400 colorimeter (Konica Minolta, SP, Brazil) with standards and D65 CIE Lab (GENNADIOS et al., 1996).

Texture profile analyses (TPA) of the jellies were made in penetration mode under the conditions described by SOUZA et al. (2014a). The jelly samples were compressed by $30 \%$. The parameters analyzed were hardness, adhesiveness, springiness, cohesiveness, gumminess and chewiness. An acceptance test was performed with 90 consumers, where the evaluated characteristics were color, taste, consistency and overall liking, through a 9-point hedonic scale $(1=$ extreme disliked and $9=$ extremely liked). The sensorial test was conducted over two days. On the first day the evaluation of five formulations was done and on the second, the four remaining formulations. Sensory analysis was obtained according to the local Ethics Committee, approval number 1.091.594.

In order to compare the different cultivars in relation to the physical, physicochemical and the different peach jelly obtained in relation to physicochemical, rheological and sensorial characteristics, a univariate statistical analysis (ANOVA) and Tukey test was performed to verify if there was a significant difference among the samples at a $5 \%$ significance level $(\mathrm{P} \leq 0.05)$. 


\section{RESULTS AND DISCUSSION}

The average values and the average test of the physical and physicochemical properties evaluated for the different cultivars are shown in table 1 . There was significant difference $(\mathrm{P} \leq 0.05)$ for all evaluated attributes.

As regards the size parameters of the different peach cultivars, through table 1 , it is possible to verify that the cultivars 'Bonão' and 'Diamante' stood out presenting the longest length $(88.93 \mathrm{~mm})$ and the largest diameter $(7.43 \mathrm{~cm})$, respectively. Regarding the pulp/pit ratio, the 'Bonão' cultivar showed the highest proportion of pulp (16.95). For fresh fruit consumption, is important to note that the larger the fruit and the higher the pulp/pit ratio, the greater the consumer acceptability. Thus, among the cultivars studied, the 'Bonão' is that which stands out the most because it is a larger fruit with a higher pulp/pit ratio.

Soluble solids content varied from 9.86 to $15.20^{\circ}$ Brix, the acidity ranged from 0.28 to $1.15 \mathrm{~g}$ of citric acid $100 \mathrm{~g}^{-1}$, the $\mathrm{pH}$ ranged from 3.34 to 6.06 and the ratio ranged from 9.5 to 50.92 . These are the main parameters that indicated if the fruits are more indicated for consumption in fresh form or if processing is more appropriate. In general the soluble solids contents and acidity are within the ranges reported in the literature (SOUZA et al., 2013).

In general, all peach cultivars, especially 'Centenário', 'Aurora', 'Diamante' and 'Douradão', presented high soluble solids levels. The Brix is widely related to the presence of sugars and organic acids, thus reflecting the amount of these nutrients. In relation to acidity, the less acidic were 'Centenário' and 'Douradão', that also stood out because they presented the highest soluble solids levels and the 'Aurora' cultivar stood out because of the higher $\mathrm{pH}$.

For the fruit flavor estimation, one of the most used ways is through the SS/TA ratio. This relationship (SS/TA), influenced by climatic conditions, especially by luminosity and temperature, is considered appropriate for determining fruit quality (ANTUNES et al., 2010). The higher contents of this variable is due to the high level of soluble solids and/ or the low level of acidity, and the higher the ratio, the greater the sweetness of the fruit in relation to its acidity. The 'Douradão' cultivar stood out for having a higher ratio (50.92). These characteristics demonstrated that this cultivar has high sweetness and low acidity which reflects in an optimal sweet-acid balance which is desirable for fresh fruit consumption.

As for the coloration of the different peach cultivar fruits, the color parameter $\mathrm{L}^{*}$ varied from 56.58 ('Regis') to 67.40 ('Tropical'), Chroma from 36.65 ('Centenary') to 60.66 ('Libra') and Hue from 66.35 ('Regis') to 85.58 ('Centenary'). From these results it can be verified that all the peaches have a red/yellowish coloration, and the cultivars 'Regis' and 'Diamante' differ from the others, showing a more reddish coloration. In addition, the cultivar 'Tropical' stands out for having a lighter color and 'Libra' because it has a higher color intensity/purity.

Average values and the average test of the physicochemical and rheological properties evaluated for the different peach jelly formulations are shown in table 2 and table 3, respectively. All

Table 1 - Average length (AL), average diameter (AD), pulp/pit ratio (P/P), total soluble solids (SS), total acidity (TA), pH, soluble solids/total acidity ratio (ratio), color ( $\mathrm{L}^{*}$, Chroma and Hue) in different peach cultivars.

\begin{tabular}{|c|c|c|c|c|c|c|c|c|c|c|}
\hline Cultivars & $\mathrm{AL}(\mathrm{mm})$ & $\mathrm{AD}(\mathrm{cm})$ & $\mathrm{P} / \mathrm{P}$ & $\mathrm{SS}\left({ }^{\circ} \mathrm{Brix}\right)$ & TA (\%) & $\mathrm{pH}$ & Ratio & $\mathrm{L}^{*}$ & Chroma & ${ }^{\circ}$ Hue \\
\hline 'Aurora' & $63.63^{\mathrm{bc}}$ & $4.16^{\mathrm{bc}}$ & $15.67^{\mathrm{ab}}$ & $15.20^{\mathrm{a}}$ & $0.80^{\mathrm{c}}$ & $6.06 \mathrm{a}$ & $19.00^{c}$ & $66.18^{\mathrm{ab}}$ & $38.82^{c}$ & $88.54^{\mathrm{a}}$ \\
\hline 'Biuti' & $49.16^{\mathrm{c}}$ & $4.63^{b c}$ & $10.64^{\mathrm{bc}}$ & $9.86^{\mathrm{b}}$ & $0.77^{\mathrm{c}}$ & $3.34 \mathrm{c}$ & $12.80^{\mathrm{cd}}$ & $60.40^{\mathrm{cd}}$ & $37.50^{\mathrm{c}}$ & $84.74^{\mathrm{ab}}$ \\
\hline 'Bonão' & $88.93^{\mathrm{a}}$ & $5.26^{\mathrm{bc}}$ & $16.95^{\mathrm{a}}$ & $11.70^{\mathrm{b}}$ & $1.04^{\mathrm{b}}$ & $3.59 \mathrm{c}$ & $11.25^{\mathrm{d}}$ & $65.50^{\mathrm{ab}}$ & $47.51^{\mathrm{bc}}$ & $77.75^{\mathrm{bc}}$ \\
\hline 'Diamante' & $69.40^{\mathrm{b}}$ & $7.43^{\mathrm{a}}$ & $9.53^{c}$ & $14.03^{\mathrm{a}}$ & $1.15^{\mathrm{a}}$ & $3.62 d$ & $12.2^{\mathrm{cd}}$ & $61.62^{\mathrm{abc}}$ & $38.31^{\mathrm{c}}$ & $77.64^{\mathrm{c}}$ \\
\hline 'Douradão’ & $63.67^{\mathrm{bc}}$ & $6.10^{\mathrm{ab}}$ & $10.42^{\mathrm{bc}}$ & $14.26^{\mathrm{a}}$ & $0.28^{\mathrm{e}}$ & $4.21 \mathrm{~b}$ & $50.92^{\mathrm{a}}$ & $65.33^{\mathrm{ab}}$ & $47.97^{\mathrm{abc}}$ & $77.09^{c}$ \\
\hline 'Libra' & $70.56^{\mathrm{b}}$ & $5.13^{\mathrm{bc}}$ & $13.83^{\mathrm{abc}}$ & $10.83^{b}$ & $1.14^{\mathrm{a}}$ & $3.49 \mathrm{c}$ & $9.5^{\mathrm{d}}$ & $61.45^{\mathrm{abc}}$ & $60.66^{\mathrm{a}}$ & $72.39 \mathrm{~cd}$ \\
\hline 'Regis' & $50.30^{\mathrm{c}}$ & $4.33^{b c}$ & $11.66^{\mathrm{abc}}$ & $10.00^{\mathrm{b}}$ & $0.54^{\mathrm{d}}$ & $4.06 \mathrm{~b}$ & $18.51^{\mathrm{c}}$ & $56.58^{\mathrm{d}}$ & $58.38^{\mathrm{ab}}$ & $66.35^{\mathrm{d}}$ \\
\hline 'Tropical' & $46.83^{c}$ & $3.90^{c}$ & $12.05^{\mathrm{abc}}$ & $10.83^{\mathrm{b}}$ & $0.31^{\mathrm{e}}$ & $4.56 \mathrm{~b}$ & $34.93^{b}$ & $67.40^{\mathrm{a}}$ & $52.03^{\mathrm{ab}}$ & $85.13^{\mathrm{a}}$ \\
\hline CV(\%) & 9.80 & 13.94 & 15.62 & 5.44 & 4.25 & 5.21 & 10.33 & 3.65 & 9.70 & 3.03 \\
\hline
\end{tabular}

*Mean values with common letters in the same column indicate that there is no significant difference among samples (P<0.05) by Tukey's mean test.

${ }^{* *}$ Total acidity: $\mathrm{g}$ citric acid $100 \mathrm{~g}^{-1}$ f.w. 
Table 2 - Soluble Solids (SS), pH, total acidity (TA), color (L*, Chroma and Hue) in peach jelly.

\begin{tabular}{|c|c|c|c|c|c|c|}
\hline Cultivars & SS & $\mathrm{pH}$ & TA & $\mathrm{L}^{*}$ & Chroma & ${ }^{\circ}$ Hue \\
\hline 'Aurora' & $65.6^{\mathrm{abc}}$ & $4.08^{b}$ & $0.26^{\mathrm{bc}}$ & $29.93^{\mathrm{cd}}$ & $30.09^{\text {bcd }}$ & $79.16^{b}$ \\
\hline 'Biuti' & $62.3^{\mathrm{cd}}$ & $3.66^{\mathrm{d}}$ & $0.46^{\mathrm{ab}}$ & $32.97^{\mathrm{c}}$ & $34.20^{\mathrm{bc}}$ & $68.69^{\mathrm{e}}$ \\
\hline ‘Bonão’' & $67.0^{\mathrm{ab}}$ & $3.85^{\mathrm{c}}$ & $0.42^{\mathrm{abc}}$ & $41.14^{\mathrm{a}}$ & $43.95^{\mathrm{a}}$ & $74.83^{\mathrm{cd}}$ \\
\hline 'Centenário' & $67.6^{\mathrm{ab}}$ & $4.59^{\mathrm{a}}$ & $0.24 b^{c}$ & $25.64^{\mathrm{e}}$ & $29.72^{\mathrm{cd}}$ & $72.14^{\mathrm{d}}$ \\
\hline 'Diamante' & $53.3^{d}$ & $3.81^{\mathrm{cd}}$ & $0.41^{\mathrm{abc}}$ & $32.81^{\mathrm{cd}}$ & $26.22^{\mathrm{d}}$ & $76.44^{\text {cd }}$ \\
\hline 'Douradão' & $69.6^{\mathrm{a}}$ & $4.56^{\mathrm{a}}$ & $0.21^{\mathrm{c}}$ & $28.88^{d}$ & $33.15^{\mathrm{bc}}$ & $81.2^{\mathrm{a}}$ \\
\hline 'Libra' & $59.0^{\mathrm{c}}$ & $3.64^{\mathrm{d}}$ & $0.52^{\mathrm{ab}}$ & $37.43^{b}$ & $32.48^{b c}$ & $79.12^{\mathrm{b}}$ \\
\hline 'Regis' & $63.3^{\text {bcd }}$ & $3.82^{\text {cd }}$ & $0.28^{\mathrm{abc}}$ & $31.83^{\mathrm{cd}}$ & $34.41^{\mathrm{b}}$ & $77.20^{\mathrm{c}}$ \\
\hline 'Tropical' & $61.0^{\mathrm{c}}$ & $4.45^{\mathrm{a}}$ & $0.19^{c}$ & $29.08^{d}$ & $31.23^{\mathrm{bc}}$ & $82.29^{\mathrm{a}}$ \\
\hline $\mathrm{CV}(\%)$ & 2.50 & 1.60 & 24.41 & 3.17 & 4.77 & 0.83 \\
\hline
\end{tabular}

*Mean values with common letters in the same column indicate that there is no significant difference between samples $(\mathrm{P} \leq 0.05)$ by Tukey's mean test.

Total acidity: g citric acid $100 \mathrm{~g}^{-1}$ f.w.

analyzed parameters were significant $(\mathrm{P} \leq 0.05)$ for the jelly made with different peach cultivars.

Through the averages table (Table 2) it can be verified that, with the exception of the cultivars 'Biuti', 'Libra' and 'Diamante', the jellies presented similar solids content (61-67.6 ${ }^{\circ}$ Brix). The jellies obtained from the cultivars 'Centenário', 'Tropical', 'Aurora' and 'Douradão' were characterized by higher $\mathrm{pH}$ values and the cultivars 'Biuti', 'Libra' and 'Diamanta' characterized by higher acidity values. The jelly obtained by the cultivar 'Douradão' and 'Centenária' had a $\mathrm{pH}$ higher than 4.5 , so to maintain the safety limit it is advisable to manipulate the $\mathrm{pH}$ during processing through the amount of citric acid added.
In relation to color, it can be seen from table 2 that the 'Bonão' cultivar resulted in a lighter jelly and with greater color intensity/purity than the others. The 'Biuti' cultivar resulted in a darker jelly compared with the others. In general when compared to the fruit in fresh form, the jelly presented became redder and darker, possibly due to the concentration and the reactions that occur during the heating, such as the Maillard reaction.

In relation to the texture, it can be seen from the table of means (Table 3 ) that the jelly obtained with the cultivar 'Biuti' is characterized by resulting in a jelly with the highest hardness, adhesiveness and gumminess values. That is, this cultivar originated a

Table 3 - Hardness (Hard), adhesiveness (Adhe N/s), springiness (Sprin), cohesiveness (Cohe), gumminess (Gummi N) and chewiness (Chew) in peach jelly.

\begin{tabular}{|c|c|c|c|c|c|c|}
\hline Cultivars & Hard & Adhe & Sprin & Cohe & Gummi & Chew \\
\hline 'Aurora' & $0.06^{\mathrm{b}}$ & $0.22^{\mathrm{de}}$ & $0.99^{b}$ & $0.82^{\mathrm{ab}}$ & $0.05^{b}$ & $0.05^{\mathrm{b}}$ \\
\hline 'Biuti' & $0.47^{\mathrm{a}}$ & $1.23^{\mathrm{a}}$ & $0.98^{\mathrm{b}}$ & $0.37^{\mathrm{c}}$ & $0.17^{\mathrm{a}}$ & $0.17^{\mathrm{ab}}$ \\
\hline 'Bonão' & $0.05^{\mathrm{b}}$ & $0.09^{\text {ef }}$ & $1.28^{\mathrm{b}}$ & $0.77^{\mathrm{b}}$ & $0.04^{\mathrm{b}}$ & $0.06^{\mathrm{b}}$ \\
\hline 'Centenário' & $0.07^{b}$ & $0.46 b^{c}$ & $0.99^{\mathrm{b}}$ & $0.83^{\mathrm{ab}}$ & $0.06^{\mathrm{b}}$ & $0.06^{\mathrm{b}}$ \\
\hline 'Diamante' & $0.10^{\mathrm{b}}$ & $0.02^{\mathrm{f}}$ & $4.01^{\mathrm{a}}$ & $1.05^{\mathrm{a}}$ & $0.10^{\mathrm{b}}$ & $0.40^{\mathrm{a}}$ \\
\hline 'Douradão' & $0.08^{\mathrm{b}}$ & $0.61^{\mathrm{b}}$ & $0.99^{\mathrm{b}}$ & $0.81^{\mathrm{ab}}$ & $0.06^{\mathrm{b}}$ & $0.06^{\mathrm{b}}$ \\
\hline 'Libra' & $0.08^{b}$ & $0.02^{\mathrm{f}}$ & $3.75^{\mathrm{a}}$ & $1.06^{\mathrm{a}}$ & $0.09^{b}$ & $0.37^{\mathrm{a}}$ \\
\hline 'Régis' & $0.11^{b}$ & $0.36^{\text {cd }}$ & $0.97^{\mathrm{b}}$ & $0.43^{\mathrm{c}}$ & $0.04^{\mathrm{b}}$ & $0.04^{\mathrm{b}}$ \\
\hline 'Tropical' & $0.06^{\mathrm{b}}$ & $0.26^{\text {de }}$ & $1.00^{\mathrm{b}}$ & $0.84^{\mathrm{ab}}$ & $0.05^{\mathrm{b}}$ & $0.05^{\mathrm{b}}$ \\
\hline $\mathrm{CV}(\%)$ & 37.20 & 16.54 & 15.29 & 11.49 & 37.05 & 38.42 \\
\hline
\end{tabular}

${ }^{*}$ Mean values with common letters in the same column indicate that there is no significant difference between samples $(\mathrm{P} \leq 0.05)$ by Tukey's mean test. 
more rigid, firm, adhesive and gummy jelly. Conversely, 'Libra' and 'Diamante' cultivar jellies have greater springiness, cohesiveness and chewiness.

Several factors may explain the texture change among jellies made from different peach cultivars. The amount of sugar present in each cultivar, $\mathrm{pH}$, acidity and soluble pectin content are factors that can influence the gelation and, the texture of the final product. Significant difference was verified among the jellies obtained from different peach cultivars for color and overall liking $(\mathrm{P} \leq 0.05)$ (Table 4$)$.

In general, the jelly formulations presented an excellent sensory acceptance for all the sensorial attributes evaluated, with average scores generally varying between the hedonic terms "moderately liked" and "liked very much" (Table 4). This clearly indicates that as expected, peach-based products are highly accepted and appreciated by Brazilians. In addition, it can be clearly observed that all cultivars studied have high processing potential.

It can be clearly seen that the formulation elaborated with the 'Bonão' was the least sensorial accepted. By the mean table (Table 4) it can be verified that this cultivar had lower scores than the others for the attribute, color, which may have influenced the lowest score observed for the overall liking attribute. The jelly obtained from the 'Bonão' was characterized by being different from the others by being darker and showing higher color intensity (Table 2). This suggested that color has a great influence on the acceptability of peach jelly and that the consumer prefers lighter or clearer jellies. Although, this cultivar has been the least accepted, it is still highly indicated for processing due to high sensory acceptance and the fact that color is an attribute that can be easily altered in order to please the consumer. It was previously observed that the jellies presented wide differences among themselves in relation to the physicochemical and rheological attributes; however, since no significant difference in the acceptability was detected for the flavor attribute and the consistency, these attributes had no influence on the sensory quality of the jelly.

Generally the most suitable cultivars for processing are the least accepted for fresh consumption, thus, it is possible to provide a consumption destination for the all the cultivars in the best way. The cultivars 'Aurora', 'Douradão' and 'Tropical', for example, are destined for table consumption, thus, since there already is a large consumption destination, it may be less interesting to destine them for processing. However, the other cultivars that are destined for dual purposes ('Biuti' and 'Régis') or destined for processing (Diamond) may indeed, be more interesting and suitable for processing. In addition, as it is feasible to prepare jellies from all the studied peach cultivars, the adaptation, susceptibility to pests, production cost and yield of the different cultivars are some factors that should help to indicate which are the most interesting cultivars to be cultivated and destined for industrialization.

\section{CONCLUSION}

In this study, it can be verified that the evaluated peach cultivars presented great variability among themselves in relation to physical and physicochemical characteristics. The jellies elaborated from the different peach cultivars; although, presenting high variability in relation to the physicochemical and rheological parameters, presented similar and high sensory acceptance. Therefore, it was concluded that all studied peach cultivars are indicated for processing.

Table 4 - Sensory characteristics of the peach jellies obtained from different cultivars.

\begin{tabular}{llccr}
\hline Formulations & Color & Taste & Consistency & Overall Liking \\
\hline 'Aurora' & $7.33^{\mathrm{ab}}$ & $7.10^{\mathrm{a}}$ & $7.47^{\mathrm{a}}$ & $7.39^{\mathrm{ab}}$ \\
\hline 'Biuti' & $7.64^{\mathrm{ab}}$ & $7.50^{\mathrm{a}}$ & $7.41^{\mathrm{a}}$ & $7.53^{\mathrm{ab}}$ \\
'Bonão' & $7.25^{\mathrm{b}}$ & $6.82^{\mathrm{a}}$ & $7.10^{\mathrm{a}}$ & $6.97^{\mathrm{b}}$ \\
'Centenário' & $7.84^{\mathrm{a}}$ & $7.33^{\mathrm{a}}$ & $7.60^{\mathrm{a}}$ & $7.64^{\mathrm{a}}$ \\
'Diamante' & $7.61^{\mathrm{ab}}$ & $7.34^{\mathrm{a}}$ & $7.21^{\mathrm{a}}$ & $7.49^{\mathrm{ab}}$ \\
'Douradão' & $7.82^{\mathrm{ab}}$ & $7.22^{\mathrm{a}}$ & $7.41^{\mathrm{a}}$ & $7.40^{\mathrm{ab}}$ \\
'Libra' & $7.71^{\mathrm{ab}}$ & $7.37^{\mathrm{a}}$ & $7.42^{\mathrm{a}}$ & $7.37^{\mathrm{ab}}$ \\
'Régis' & $7.81^{\mathrm{ab}}$ & $7.47^{\mathrm{a}}$ & $7.32^{\mathrm{a}}$ & $7.50^{\mathrm{ab}}$ \\
\hline 'Tropical' & $7.61^{\mathrm{ab}}$ & $7.30^{\mathrm{a}}$ & $7.34^{\mathrm{a}}$ & $7.29^{\mathrm{ab}}$ \\
\hline
\end{tabular}

*Mean values with common letters in the same column indicated that there is no significant difference among samples $(\mathrm{P} \leq 0.05)$ by Tukey's mean test. 


\section{ACKNOWLEDGEMENTS}

To Fundação de Amparo a Pesquisa de Minas Gerais (FAPEMIG), Conselho Nacional de Desenvolvimento Científico e Tecnológico $(\mathrm{CNPq})$ and Coordenação de Aperfeiçoamento de Pessoal de Nível Superior (CAPES) for the financial support. Process number 405466/2016-1.

\section{REFERENCES}

ALVARES, C.A. et al. Köppen's climate classification map for Brazil. Meteorologische Zeitschrift, v.22, p.711-728, 2013. Available from: <https://www.schweizerbart.de/papers/metz/detail/22/82078/ Koppens climate classification map for Brazil>. Accessed: Apr. 06, 2017. doi: $10 . \overline{1} 127 / 0941-29 \overline{4} 8 / 2013 / 0 \overline{5} 07$.

ANTUNES, L.E.C. et al. Yield and quality of strawberry cultivars. Horticultura Brasileira, v.28, p.222-226, 2010. Available from: <http://www.scielo.br/scielo.php?script=sci_ar ttext\&pid=S0102-05362010000200015>. Accessed: Apr. 05, 2017. doi: 10.1590/S0102-05362010000200015.

ARAÚJO, J.P.C. et al. Influence of the renewal pruning and control of the rust in the carbohydrate reserves and production of precocious peach tree. Revista Brasileira de Fruticultura, v.30, p.331-335, 2008. Available from: <http://www.scielo.br/ scielo.php?script $=$ sci arttext $\&$ pid $=\mathrm{S} 0100-2945200800020001>$. Accessed:Apr. 05, 2017. doi: 10.1590/S0100-29452008000200011.

BARBOSA, W. et al. Advances in low-chilling peach breeding at Instituto Agronômico, São Paulo State, Brazil. Acta Horticulturae, v.872, p.147-150, 2010. Available from: <http://www.actahort.org/ books/872/872 17.htm>. Accessed: Apr. 06, 2017. doi: 10.17660/ ActaHortic.2010.872.17.

CANTÍN, C.M. et al. Evaluation of the antioxidant capacity, phenolic compounds, and vitamin $\mathrm{C}$ content of different peach and nectarine [Prunus persica (L.) Batsch] breeding progenies.
Journal of Agricultural and Food Chemistry, v.57, p.45864592, 2009. Available from: <http://pubs.acs.org/doi/abs/10.1021/ jf900385a>. Accessed: Apr. 06, 2017. doi: 10.1021/jf900385a.

GENNADIOS, A. etal. Mechanical and barrier properties of egg albumen films. Journal of Food Science, v.61, p.585-589, 1996. Available from: $\quad<$ http://onlinelibrary.wiley.com/doi/10.1111/j.1365-2621.1996. tb13164.x/abstract>. Accessed: Apr. 06, 2017. doi: 10.1111/j.13652621.1996.tb13164.x.

IAL (INSTITUTO ADOLFO LUTZ). Normas Analíticas do Instituto Adolfo Lutz. São Paulo, 2005. Available from: $<$ http://www.ial.sp.gov.br/ial/publicacoes/livros/metodos-fisicoquimicos-para-analise-de-alimentos>. Accessed: Apr. 06, 2017.

INSTITUTO BRASILEIRO DE ESTATÍSTICA (IBGE). Censo Agropecuário. Available from: $<$ http://www.sidra.ibge.gov.br/bda/ tabela/listabl.asp?c=1613\&z=p\&o=23>. Accessed: Dec. 16, 2016.

KAPOOR, S.; RANOTE, P.S. Antioxidant components and physico-chemical characteristics of jamun powder supplemented pear juice. Journal of Food Science and Technology, v.53, p.2307-2316, 2016. Available from: <https://www.researchgate. net/publication/302486164_Antioxidant_components_ and_physico-chemical_characteristics_of_jamun_powder_ supplemented_pear_juice>. Accessed: Aug. 01, 2016. doi: 10.1007/s13197-016-2196-x.

SOUZA, F.B.M. et al. Fruit production and quality of selections and cultivars of peach trees in Serra da Mantiqueira, Brazil. Bragantia, v.72, p.133-139, 2013. Available from: <http://www.scielo.br/ scielo.php?script $=$ sci arttext\&pid=S0006-87052013000200004>. Accessed: Aug. 12, 2016. doi: 10.1590/S0006-87052013005000024.

SOUZA, V.R. et al. Evaluation of the jelly processing potential of raspberries adapted in Brazil. Journal of Food Science, v.79, p.407-412, 2014. Available from: <http://www.ncbi.nlm. nih.gov/pubmed/24467459>. Accessed: Aug. 12, 2016. doi: $10.1111 / 1750-3841.12354$. 